\title{
消防防災システムの阻害要因のペトリネットシミュレーションに関する基礎的研究 Study on Petri-net Simulation System of Hazard Factors against Fire Prevention Systems
}

\author{
木俣 昇*，熟見 育男** \\ By Noboru KIMATA, Ikuo SUMI
}

\section{1・まえがき}

今般の阪神淡路大地震では, 消防システムを始め としたいわゆる防災システムは全く機能しなかった といっても過言ではない. その原因として，”予想 外の事態云々”ということをしばしば耳にする。し かし，防災システムとはそもそも異常事態の中で発 動されるものであり，予想外はいわば常態である. その混乱の中での機能性を検討する力が，防災計画 システムには求められる．その意味では計画側に重 大な欠陥があったことを示唆している.

システム的方法には，同定という概念に代表され るように，要素についても，それらの間の関係につ いても確定化指向を強い，通常時の計画に関しては， この特性は計画案に信頼性を与えるものとなり，シ ステム論的方法が採用される大きな理由となる.し かし，上述したように異常時の混乱の中で機能性を 取り扱う防災計画では，それだけでは不十分であり， 要素についても, 関係についても, 逆に批判的見直 しを促す不確定化力や発想促進化力も求められてい るといえよう.

「要素」とそれらの間の「関係」から全体に迫る というシステム論的方法 ${ }^{1)}$ には，このような特性が 本来的に備わっている. それを具体的な形で引き出 すために，本論文では，防災計画のシステム論的方

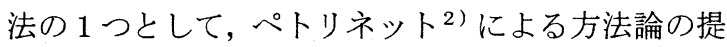
案を試みる.

著者らは，交通渋滞問題に対するペトリネットシ ミュレーションシステムの開発研究 ${ }^{3)}$ ５) を通して,

キーワード : 防災計画, 計画手法論, システム分析

*正会員工博 金沢大学教授 工学部土木建設工学科

（广920 金沢市小立野 2-40-20 TEL 076-234-4914 FAX 076-234-4915） **学生会員 金沢大学大学院 工学研究科 土木建設工学専攻 （䂆920 金沢市小立野 2-40-20 TEL 076-234-4914 FAX 076-234-4915）
この方法論が，

(1)独特の記号によるネットという形での視覚的な 表現系の使用，

(2)そのネット構造の単純性，共通性より発生する 結合化力,

(3)対象記述の表現系とその駆動系アルゴリズムの 分離性

といった特徵を持つことを明らかにしてきている. これらの諸特徵は, 上述した要素や関係の見直しの 促進に有利に働くことが期待される.

より直接的には，本論文では，震害による種々の 防災活動の阻害要因の生起問題を取り上げる.この 問題は，ペトリネットの基本概念の 1 つである抑止 アークを利用することで，システム的表現化が可能 で，さらに，この表現化の成否が，ペトリネット手 法の導入の原理的可能性と限界を具体的に論じる突 破口となると考えてのことである.

そこで，本論文では，まず，防災活動を制約する 制約型阻害と，活動を不能にする切断型阻害に大別 し，それぞれの型の阻害要因の生起と，それに伴う 混乱の部分ペトリネットモデル化案を提示する. ま た，この部部ネットレベルでも，阻害事象の事前発 生対策の実施の有無や，阻害発生後の対応策計画の 良否の組み入れといった発想促進化が可能となるこ とを示す．次に，災害発生時間帯によっては最大の 阻害要因となる可能性のある，一般車両による緊急 車両の走行阻害の問題を取り上げ，そのペトリネッ トモデルを提案する。そして，このネットも既開発 の駆動系でシミュレーションが可能であることを確 認し，本方法の原理的可能性の一端を示す.

最後に，これらのモデルを消防防災システムの見 直しに適用した事例研究を示す。具体的には，ペト リネットによるモデル化の手順を示し，金沢市の一 現場での地震時消防活動のマクロペトリネットモデ 


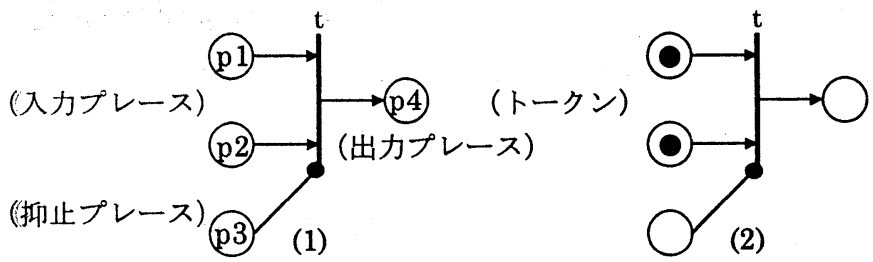

図- 1 基本ペトリネットモデル

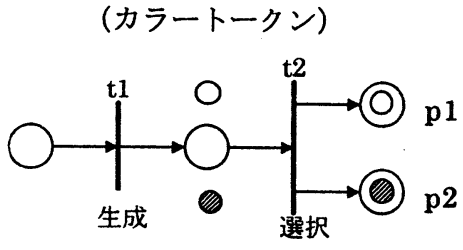

図一 2 カラーペトリネットモデル

ルを作成し，阻害要因の影響分析の概念的なシミュ レーション事例を示す.

\section{2. 阻害要因のペトリネットによる表現法}

\section{（1）ペトリネットの基本概念}

ペトリネットの基礎は，C.A. Petriによって提案 された概念だが，現在，それからはかなり離れたも のまでを差すようになっている2)。ここでも拡張さ れたペトリネットを使用する，まず，本論文で使用 するものに限定して，その基礎概念を概説する.

ペトリネットは，事象の生起による状態の推移を ネット図で記述する離散系の手法で, 図ー1の（1） に示寸ような記号によるネット図が使用される. 即 ち，事象 $(t)$ はトランジションと呼ばれ”|"で 表示され, 状態 $(\mathrm{p} 1 \sim \mathrm{p} 4)$ はプレースと呼ばれ, ” ○”で表示される.この両者の関係を，図に示す 3 種類（入力, 出力, 抑止）のアークで結合したもの がペトリネット図である。このような単純・共通構 造を持つ基本ネットが結合化され，全体のシステム ネット図が構成されることになる.

具体的な状態は，図一1の（2）に示すように， ネット図のプレースにトークンと呼ばれる”○”を マーキングすることで表現する.このマーキング状 態をトランジションの”発火”という駆動アルゴリ ズムで推移させることで, システムの状態をダイナ ミックに記述するという方法を取る。そして，この 発火も, 以下のような非常に単純なルールに従うと ころにも特徴がある。即ち，

1）その入カプレースの全てにマーキングがなさ れていて,

2）抑止プレースには逆に全てマーキングがない ときにのみ，当該トランジションは発火し，

3）その全ての入力プレースからトークンを（1 個ずつ）取り去り，

4）出力プレースの全てにトークンを（1 個ずつ） 配置する

という共通のルールである.

時間的記述性の付与は，トークンにプレースタイ マを与え，それが切れた時点でマーキング状態とな るという処理で可能となる，また，防災計画の場合 には，災害規模によって阻害要因の生起状況が異な る.このような問題を取り扱うために，図一 2 に示 すような特殊なトランジションとカラートークンを 導入する. 即ち, 指定された比率でカラートークン を生成する生成トランジション $\mathrm{t} 1$ と, 生成された卜 一クンのカラーによって出カプレースを選択する選 択トランジション t 2 の使用である. 図一 2 では, t 1 によって，2 種類の災害規模を意味するカラートー クン（○と円）を，予想される確率を指定し生成し， その結果を $\mathrm{t} 2$ によって, 1 か $\mathrm{p} 2$ のいずれかに出力 し, その後の状況推移系列が, 災害規模に応じて異 なるネット例となっている.

（2）阻害要因の基本ペトリネットモデル

防災システムの発動時には, 計画通りの活動を阻 害する要因の発生が常に付随する. 通常時の火災で も，通報の遅れや，一般車両による緊急車両の走行 阻害が発生する可能性がある. 地震時には，さらに 多種多様な活動阻害要因が発生することになる ${ }^{6)}$.

これらの阻害要因は，その阻害度に着目すれば， 活動は可能だが計画通りに機能することを阻害する 制約型のものと，活動がある期間は全く不可能とな る切断型のものとに分けることができるだろう。も ちろんこの両者の区別は相対的な面を持っている. この項では，そのような面を含めて，まず，この 2 つの型の阻害要因のペトリネットによる基本表現法 を提案する.

図一 3 は，上述の制約型阻害要因の基本ペトリネ ットモデルである.この図では, トランジション $\mathrm{t} 1$, 


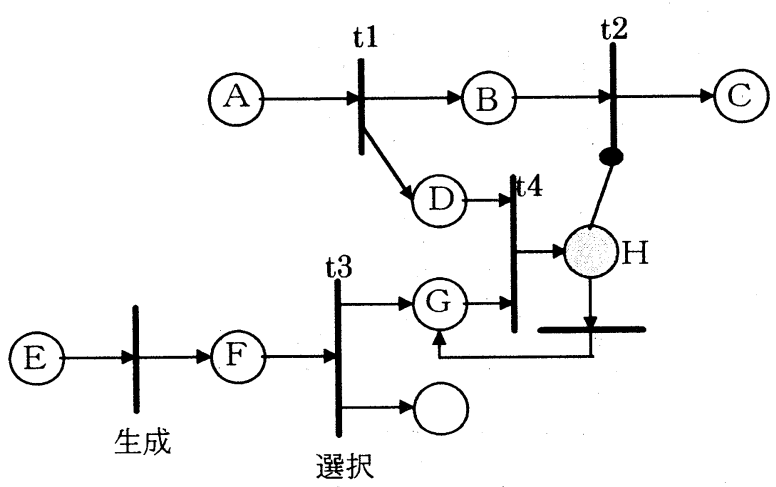

図-3 制約型阻害のペトリネットモデル

t2 で示される“計画された活動”が，t4 というトラ ンジションの発火で引き起こされる阻害要因の生起 状態, プレース $\mathrm{H}$ によって制約的阻害を受ける状況 をペトリネットモデル化したものである.

まず，このネット図の下方が災害に伴う阻害要因 の発生ネットである.このネットでは, 本章の (1) で述べた生成トランジションで災害規模に応じたカ ラートークンが生成され，それが選択トランジショ ン $\mathrm{t} 3$ で判別され, 阻害を発生させる規模の場合には プレース G にトークンがマーキングされるように 設定している.そして，このトークンにはタイマは 与えないとする.

この状態で, $\mathrm{t} 1$ が発火した状況を考える. で概説したように,この発火に伴って $\mathrm{t} 1$ の出カプレ 一スである B と D にトークンがマーキングされる. B のトークンには “計画された活動” , 即ち $\mathrm{t} 1$ の活 動時間をタイマとして与える. 一方, Dのトークン にはタイマを与えないとすれば， t4 の発火条件 （（1）の1），2））が成立し，t4 は直ちに発火 し，Hにトークンがマーキングされることになる. 図一 3 では, このプレースから $\mathrm{t} 2$ に抑止アークが伸 ばされている.そのために，t2 の発火は抑止され， B のトークンのタイマが切れても， $\mathrm{H}$ のトークンの タイマが切れるまでは“計画された活動”の開始が 遅延されることになる．さらにいえば，このネット 図は,この阻害が $\mathrm{t} 1$ の発火毎に以後も繰り返される モデルとなっている.

図一 4 は，切断型阻害要因の基本ペトリネットモ デルである.こちらでは, 図- 3 とは異なり, 阻害 要因の生起は，計画的活動の事象の系列とは全く別 に進行し，災害規模に応じて生起されたカラートー

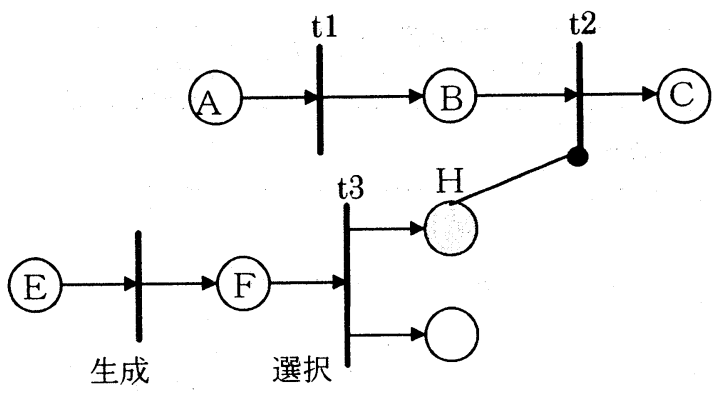

図-4 切断型阻害のペトリネットモデル

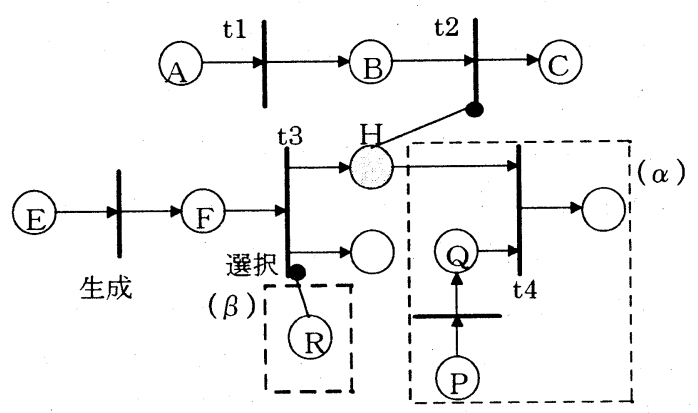

図 -5 切断型阻害の対策・復旧ペトリネットモデル クンが判別され，プレースHにトークンがマーキン グされる.このプレースからトランジション $\mathrm{t} 2$ に抑 止アークが伸ばされるネットとなっている.

プレースHは, 図一 3 のネットとは異なり, 出力 トランジションを持たない. そのために, 一度トー クンがマーキングされると消えることはなく，その 後は, $\mathrm{t} 2$ は全く発火することができなくなる，その 意味で活動が切断的に阻害されてしまうというモデ ルになっている.

ペトリネットの導入理由として, 要素ないしは関 係の不確定化, 発想促進化力を挙げた. この部分ネ ットのレベルでも，この特徵を示すことができる.

上で見たように，図ー4では，切断型の阻害が一 度発生すると, 計画的活動は文字通り切断されてし まう。しかし，適切な対応策が取られれば，再開が 可能なのが実際であろう. 図一 5 は, 図一 4 に破線 部の部分ネットを結合させたものである、破線部

（ $\alpha ）$ は，上述の対応策の部分ネットであり，この 結合化によって, 阻害と計画活動との関係は不確定 化されることになる。

即ち, $\mathrm{P}$ を対応策の開始準備状態， $\mathrm{t} 4$ を対応策の 㬰施開始，Q 老対応策の実行状態とするこのネット 


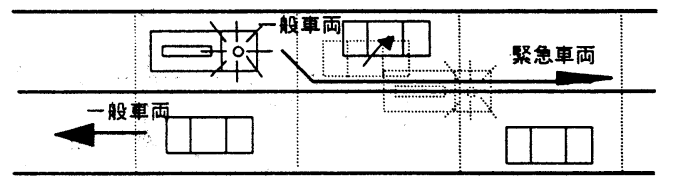

図-6 緊急車両走行の概念図

では，Q上のトークンのタイマが切れた段階で，対 忘の完了を意味するトランジション t5 が発火可能 となり，Hのトークンは消えることになる．その結 果, 抑止が解除され, 計画的活動事象 $\mathrm{t} 2$ を再開させ ることが可能となる.

また, この切断型阻害要因の事前対策として, 例 えば液状化現象対策の有無も，簡単に組み入れるこ とができる．破線部（ $\beta$ ）の結合化がそれである. 即ち，プレース $\mathrm{R} へ$ のトークンの配置の有無により， 選択トランジション $\mathrm{t} 3$ 一の抑止状況を変える工夫 をすればよい. しかも，このような変更，あるいは 精緻化を行っても，（1）で述べたように，それら のシミュレーションのための駆動系アルゴリズムは 変更不要であり, 発想や提案を直ちにシミュレーシ ヨンで検討寸ことが可能となる.この実行性につい ては, 後で確認する.

上述の議論で，ここで提案しようとしている方法 論の特徵と可能性が一応示せた。 それと同時に，プ レースタイマが重要な役割を担ってくることも明ら かとなった.これについては，具体的な事例に即し た調查研究が必要になる，場合によっては，これに もペトリネットによるモデル化が有効となる. 次章 では，その 1 例について述べることにする.

\section{3. 緊急車両の走行阻害のペトリネットモデル}

\section{（1）一般車両による走行阻害の基本部分モデル}

車社会の今日，緊急車両の計画的走行の阻害要因 として，一般車両の存在を軽視することは許されな (7)。ここでは，4.で論じる消防防災活動のマク ロペトリネットモデルにおけるプレースタイマの設 定を目的に，一般車両が緊急車両走行に与える阻害 評価のペトリネットモデルの開発例を示す。

図-6は，片側 1 車線道路で緊急車両が走行して きた場合の概念図である.一般車両は，後方から走

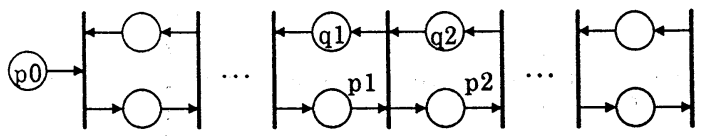

図- 7 一般車両の走行部分

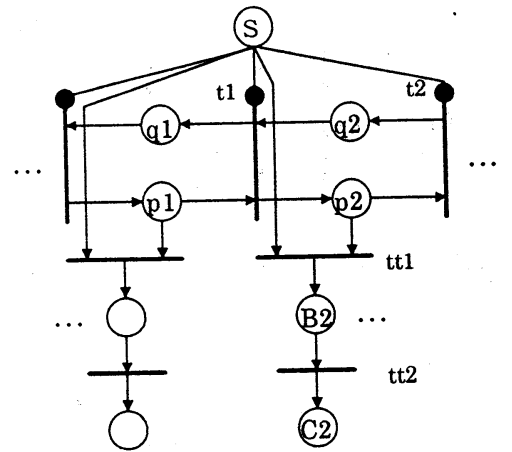

図-8 一般車両路肩移動部分モデル

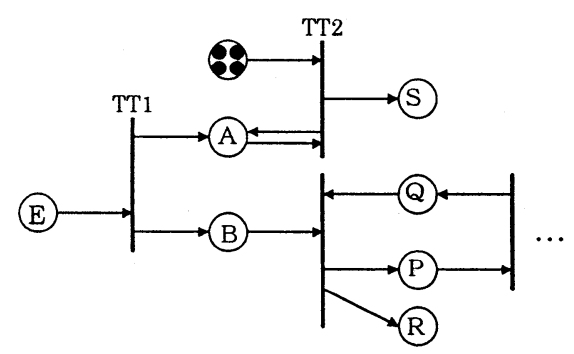

図-9 緊急車両の到着とサイレン部の部分モデル

行してきた緊急車両のサイレンを聞いて, 路肩へと 移動し，停車する。一方，緊急車両は，一般車両の 移動完了によって確保された道路区間を利用して走 行することを示している，この概念図を基に，単路 部での走行のペトリネットモデルを作成する.

図一 7 は，著者らの既開発の一般車両の走行のネ

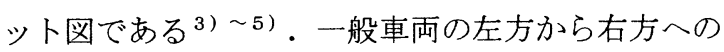
進行を，道路を閉塞区間に分割し，モデル化したも ので, p0 で生成されたトークン (一般車両) は, 前 方閉塞区間（ネット図の上方のプレース）の空きを 条件にトランジション, ‥t $1, \mathrm{t} 2 \cdots$ を発火させて, プレース, $\cdots \mathrm{p} 1, \mathrm{p} 2 \cdots$ と移動するネットモデルで ある.これらの一般車両は, 緊急車両のサイレンを 聞き，路肩へ移動し，停車する. 図一8は，この行 動部の部分ネットである. 即ち, $\mathrm{S}$ は, サイレン音 を意味し，そのプレースから一般車両の進行トラン ジション，‥t 1 , $\mathrm{t} 2 \cdots$ に抑止アークを伸ばす。抑 止するトランジションの数は, サイレン音の有効範 囲で，消防署でのヒアリングでは，概小 $50 \mathrm{~m}$ ，本モ 


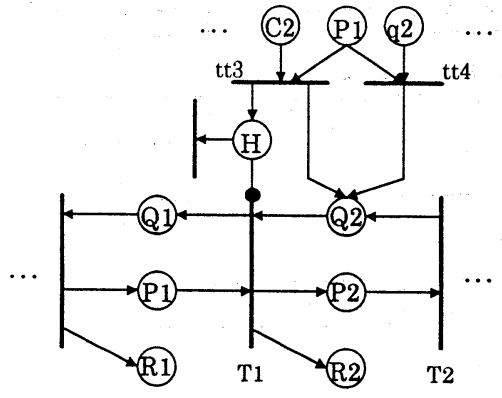

図-10 緊急車両走行の部分モデル

デルでは 7 閉塞区間となる.このネットの論理を $\mathrm{p} 2$ に存在する車両について説明すると, $\mathrm{S}$ にトークン がマーキングされると，t2 が抑止され，tt1 が発火 する. 現象的には, ブレーキを踏み, 減速し, 路肩 への移動開始を意味し, tt2 の発火により最終的に は C2 ヘトークンがマーキングされ停車完了となる.

次に，緊急車両側の部分ネットについて説明する. 図-9は, 緊急車両の到着（TT1）と，前出のサイ レン（S）のモデル化を示したものである.まず， TT1 の発火に伴い, サイレン音の有効範囲に対応し て初期配置されているトークンが TT2 を次々と発 火させ， $\mathrm{S}$ にマーキングが移る，それと同時に，緊

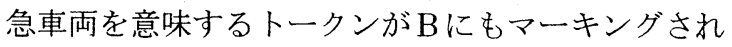
る.このネットの右下部は, 次に述べる図一10 の緊 急車両の走行部分のネットの先頭部となる.

図－10では，下方に緊急車両の走行ネットが示さ れている. プレース・的1，Q2‥緊急車両の走 行空間の空き状態を, $\cdots P 1, P 2 \cdots$ 緊急車両の存 在状態を示寸。このネット図では, 一般車両がいな い状態と, 一般車両が路肩待機の状態では, 緊急車 両の走行時間に差が出ることも意識したものとなっ ている. 即ち, 前者では, 図一 8 のネットの q2 に トークンがマーキングされている. 一方, 緊急車両 が P1 にいるとき， R1にもトークンはマーキングさ れる.したがって，この場合には，図－10のネット では tt4 が発火し, T1 の入力プレース $\mathrm{Q} 2$ にトーク ンがマ‥キングされるために，次に T1 が発火し， 緊急車両は P2 に直ちに走行することになる. 後者 の場合は，図一 8 でトークンは $\mathrm{C} 2$ に在り，q2には ない. 従って，この場合は，tt3 の方が発火する. そして， $\mathrm{Q} 2$ と $\mathrm{H}$ の 2 つトークンがマーキングさ れる. $\mathrm{T} 1$ は H から抑止を受けている.このトーク

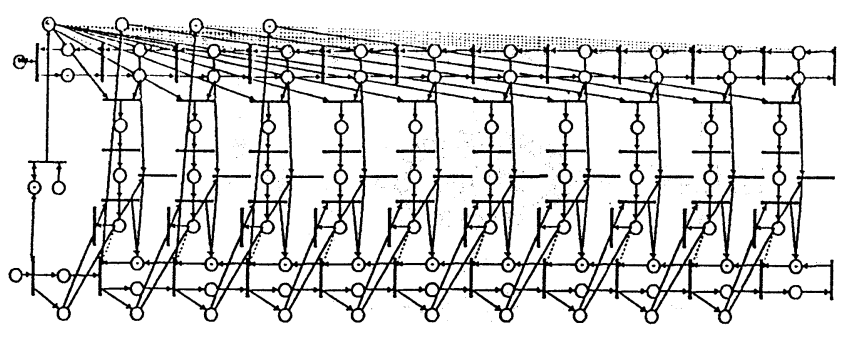

図一11 緊急車両走行のシステムネット図

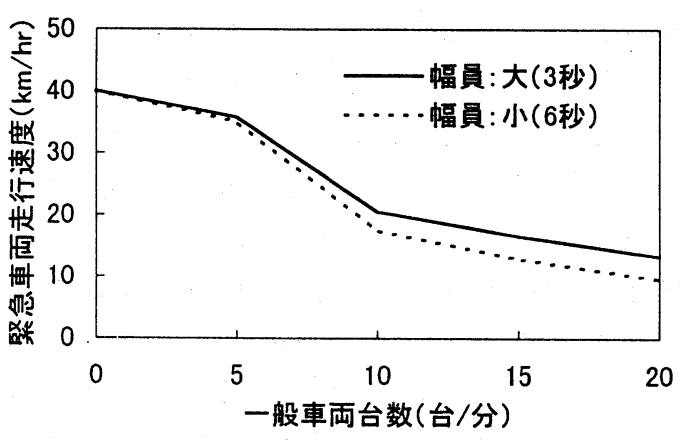

図 -12 ミクロシミュレーション結果

ンに，路肩待機に伴って確保可能な空間の大きさに 見合う走行抵抗值をタイマとして与えており，その 分 T1 の発火はさらに遅れ, 緊急車両の走行が阻害 されるモデルとなっている.このタイマの利用で, 道路幅員の差もモデル化が可能となっている.

（2）走行阻害度のシミュレーション事例

これらの基本部分ネットを対象道路の閉塞区間分 割に沿って結合化することによって，シミュレーシ ヨンのためのシステムネットが作成されることにな る. 図-11 のシステムネット図は, 概ね $67 \mathrm{~m}$ の単 路部の走行ネットで，それを 10 個の閉塞区間に分 割して，作成したものである．上部に左方向からの 一般車両の走行ネットを, 下部に同方向からの緊急 車両のネットを配置し, それらの間を図一8〜図一 10 のネットで結合化している. また, サイレンの有 効範囲は前述したように 7 閉塞区間とし，緊急車両 の移動とともにサイレンが前方へシフトするように している.

前述したように, 著者らの開発システムでは, ネ ットの登録5)だけで, シミュレーションの実行が可 能となる.このことの確認と，一般車両による緊急 車両の走行阻害度の基礎的な分析のために，このシ ステムネットのシミュレーションを実行する.

一般車両の交通量を 0 ２0 (台/分) で変化させ, 


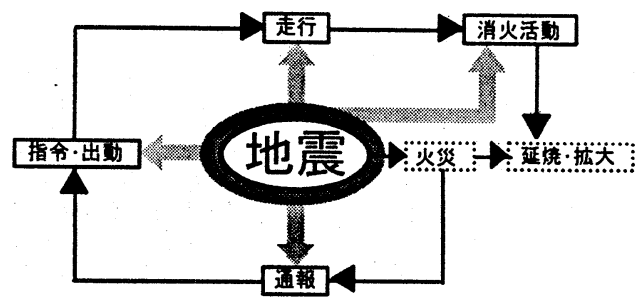

図 -13 消防防災システムの概念図

乱数初期值を変更して各ケース 5 回のシミュレーシ ヨンを実施した。また，上述の方法で幅員が広いケ 一スと狭いケースをも想定した. いずれのシミュレ ーションも既開発のシステムで問題なく実施できた. 図ー12にシミュレーション結果例を示す.

緊急車両の走行速度は, 消防計画では $40 \mathrm{~km} / \mathrm{h}$ と されている.しかし，一般車両の走行台数が 10 (台 1分）になると計画速度の半分程に低下寸るという結 果になった。また，交通量が増大するほど，道路幅 員の差の影響も大きくなるという結果となった.

4. 消防防災システムの阻害シミュレーション

\section{（1）消防防災システムのマクロペトリネットモ デルの構成}

消防防災システムは，火災発生の通報を受け，消 防署に出動指令を発する. それを受けて緊急車両が 火災現場へと走行し，現場に到着次第，消化・救助 活動を実施する. 地震時はいうまでもなく, 通常時 でもこの各プロセスに種々の阻害要因が発生すると 考えておく必要がある.この考えを概念的に示した ものが図ー13である.この視点から消防防災システ ムの検討のためのマクロペトリネットの開発を行う. この手順を示したものが，図一14である.

まず，対象地域の設定を行う。著者らが緊急車両 路の安全性評価研究 ${ }^{8)}$ で取り上げた金沢市を対象地 域とし, その中で, 火災現場上防災拠点からの走行 経路を想定した。具体的には，火災現場は，防災拠 点から約 $2 \mathrm{~km}$ 離れた, 川を挟んだ木造密集地を取 り上げる.上述の研究からこのケースでは, 緊急車 両は, 交通量や沿道条件からの評価值が中程度とい う2 区間 $(840,720 \mathrm{~m})$ の経路と, 橋梁があり危険 という 1 区間 $(520 \mathrm{~m})$ の経路を走行することにな る.この対象地域に対して, 図一13 の概念モデルよ り事象を抽出し, 通常時の消防防災システムのマク

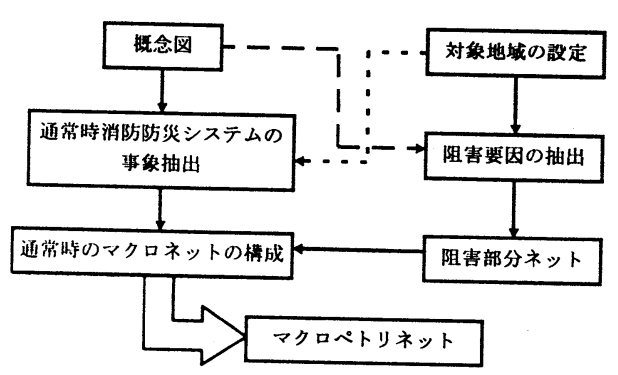

図ー14 マクロペトリネットの構成図

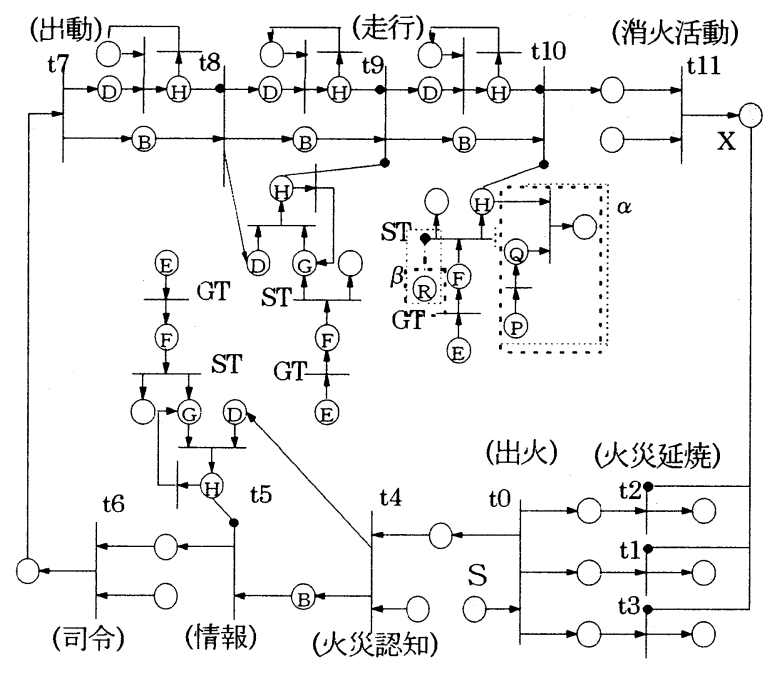

図ー15 マクロペトリネットモデル

ロペトリネットモデルを作成する．ここでの阻害は， 一般車両による制約的阻害のみを考え, 図一 3 の阻 害ネットを使用する.

次に, 上述の経路特性などを考慮して, 地震時の 阻害要因を抽出する.ここでは, 制約型阻害として は通報阻害と, 経路区間 2 での沿道建物からの路上 散乱物による阻害を考え, 切断型阻害としては経路 3 での橋梁被害を考える.これらを結合化したもの が，図-15である。即ち，図-15は，図-13 の概 念モデルと相似な形で, 外周部に出火（t0) 起引き 金とし，時計周りに消防活動の事象系列のネットを， 半時計回りに火災延焼のネットを配置し, 中央部に それらに対する上述の型の阻害ネットの結合部を配 置している.

この中央部のネットを外したものが，通常時のマ クロペトリネットモデルということになる. 通常時 のシミュレーションは，この阻害部の各ネットのプ レース $\mathrm{E} に$, 初期トークンを配置しない場合にあた る. 通常時でも，上述したように一般車両による緊 
表ー 1 マクロシミュレーション条件

\begin{tabular}{|c|c|c|c|}
\hline \multirow{2}{*}{} & \multicolumn{3}{|c|}{-般車両交通暗 (台/分) } \\
\cline { 2 - 4 } & 区間 1 & 区間 2 & 区間 3 \\
\hline 深夜·早朝 & 5 & 5 & 5 \\
\hline 日中 & 10 & 15 & 15 \\
\hline
\end{tabular}

\begin{tabular}{|c|c|c|c|}
\hline & 近信阴害 & 沿道阻害 & 標梁切断型阻害 \\
\hline 通常時 & なし & なし & なし \\
\hline 日中 & 50 秒 & 150 秒 & なし \\
\hline
\end{tabular}

急車両走行への阻害が発生する. 図一15 では, その マクロ表現として，3つの走行区間に，図ー3に示 した制約型阻害の部分ネットを組み込んでいる。そ して，それぞれの H 上のトークンに与えるプレース タイマは，それぞれの区間の交通量によって異なる として，3．の（2）で開発したモデルによるシミ ュレーション值で決定する.その意味では 3. .の (2) のモデルは，ミクロペトリネットと呼べる.

火災延焼部分のネットは，ここでは，出火点から それぞれ, 風下, 風横, 風上に $20 \mathrm{~m}$ 離れた地点への 延焼拡大（t1，t2，t3）の発生の有無としてモデル 化している。そして，それぞれのプレースタイマは， 火災延焼シミュレーション9)あるいは浜田の延焼速 度式 ${ }^{10)}$ で設定することにする.

緊急車両が現場に到着し，準備作業が整うと消火 活動開始される.この状態のとき, 図一15のマクロ モデルでは，プレースXにトークンがマーキングさ れる.このプレースよりトランジション $\mathrm{t} 1, \mathrm{t} 2, \mathrm{t} 3$ に抑止アークが伸ばされている. 即ち, このネット では，消火活動が火災の延焼拡大の前に開始可能か どうかを判定するものとなっている.

\section{（2）シミュレーションによる阻害分析}

前述したように，この方法論では，部分ネットの 結合化による拡張性に加え, 駆動系の記述系からの 分離性による汎用性にも大きな特徵がある。このネ ットも3．の（2）のシミュレーションと同様に登 録だけで実行できる.ここでは，紙面の制約上表一 1 に示寸ケースについてのシミュレーション結果の みを報告する。

図一16 がこのシミュレーション結果の要約であ る. 網掛け部が間に合わなかったケースである。ま ず, $20 \mathrm{~m}$ 以内の延焼段階で消火活動の開始が可能な ケースは，通常時で，交通量の少ない深夜・早朝の

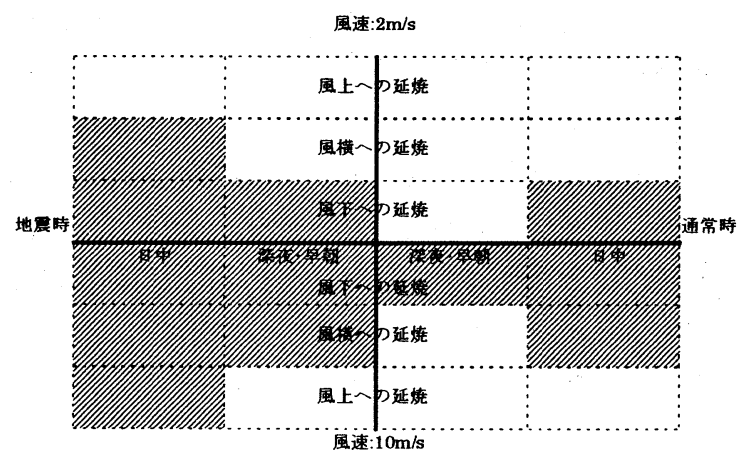

図一16 シミュレーション結果

火災で，かつ風速が $2(\mathrm{~m} / \mathrm{s})$ の場合のみという結果 になった。梁夜・早朝でも風速が $10(\mathrm{~m} / \mathrm{s})$ になれ ば，風下側への延焼阻止には間に合わない。また， 風速が $2(\mathrm{~m} / \mathrm{s})$ でも，日中の火災では通常時でも， 風下側への延焼には間に合わないという結果になっ ている.

地震時では，通報と路上散乱物による制約型の阻 害が発生すれば，風速が $2(\mathrm{~m} / \mathrm{s})$ と小さく，深夜・ 早朝の交通量が少ない場合でも，風下への延焼拡大 にも間に合わない，日中では，風横への延焼拡大に も間に合わない. 風速が $10(\mathrm{~m} / \mathrm{s})$ であれば, 深夜・ 早朝でも風横にまで延焼拡大を許し，日中では風上 までの延焼するという結果になった。

\section{5.あとがき}

防災計画の支援システムには，災害に伴う混乱の 取り扱いが強く求められる。本論文では，駆動系之 記述系が分離し，結合性，視覚性にも優れたペトリ ネットを導入することで，そのような支援システム の開発の可能性を検討した。まず，計画された活動 を阻害する要因のシステム表現が，ペトリネットの 抑止アークの活用で可能なこと，その複雑化や発想 化も結合性を利用することで可能なこと，さらに， より複雑な一般車両による緊急車両走行の阻害も, ペトリネットモデルで表現できることを示した。

次に，それらを結合化することによってさらに大 きな消防防災システムのマクロペトリネットも構成 できること，そのシミュレーションもネットの登録 だけで実行できることなどこの,方法論の特徴を確認 し, 防災計画の批判的見直しの支援に活用可能なこ 
とを示すことができたと考えている. もちろん課題 も多い. 本論文では, 防災計画へのペトリネットの 導入の可能性を示すための概念的なレベルに留まっ ており，データの想定，モデルの精緻化を含めて実 証的レベルへの発展化が必要となる. 本論文の概念 的ネットモデルは，その際に必要となる種々の分野 の人々との共同研究の批判的出発点となることにこ そ意味があるというべきかも知れない.

\section{参考文献}

1) R. Tomlinson, I. Kiss ed. : Rethinking the Process of Operational Research and Systems Analysis, Pergamon Press, 1984.

2 ) 村田忠夫 : ペトリネットの解析と応用, 近代科 学社, 1992.

3) 木俣昇, 高木秀彰 : 交通計画のためのペトリネ ット・シミュレーションシステムに関する研究, 土木計画学研究・講演集, No.16 (1), pp.127 $\sim 132,1993$.

4) 木俣昇, 高木秀彰, 黒川浩嗣 : ペトリネットに よる交通流シミュレーションシステムの開発,
土木計画学研究・論文集, No.12，pp.691 699, 1995.

5 ) 木俣昇, 高木秀彰, 黒川浩嗣 : ペトリネットに よる交通流シミュレーションシステムの実用化 と応用, 土木計画学研究・講演集, No.18 (2), pp.197 200, 1995.

6 ）家田仁，上西周子，猪俣隆行，鈴木忠徳 : 阪神 大震災における街路閉塞現象の実態とその影響, 第 1 回都市直下地震災害総合シンポジウム, pp.285 289, 1996.

7 ) 宮城県: '78 宮城県沖地震災害の教訓一実態と 課題，宝文堂，1980.

8 ）木俣昇, 石橋聡 : 地震時緊急路網のシステム信 頼性評価に関する基礎的研究, 土木計画学研 究・論文集, No.6, pp.145 152， 1988.

9 ）木俣昇 : 大震時非難計画のためのメッシュ型火 災延焼シミュレーション・システムに関する検 証, JORSJ, Vol.30, No.1, pp.59〜86, 1987.

10）日本火災学会：火災便覧，共立出版株式会社, 1984.

消防防災システムの阻害要因のペトリネットシミュレーションに関する基礎的研究

\section{木俣 昇，熟見育男}

本論文は，防災計画システムの方法論として，交通流のミクロシミュレーションに導入したペトリネット手法の 適用を試みたものである. 具体的には, 地震時の阻害要因を制約型と切断型に分け，そのペトリネット表現法を提 示している. 次に, 車社会の今日，軽視できない一般車両による緊急車両の走行阻害の問題を取り上げ，そのミク ロペトリネットモデルを作成し，シミュレーションを実施している. 最後に，これらの阻害要因ネットを組み入れ た消防防災システムのマクロペトリネットを作成し，そのシミュレーションの実行を通して，本方法論の特徴とそ の可能性を明らかにしている.

\section{Study on Petri-net Simulation System of Hazard Factors against Fire Prevention Systems by Noboru KIMATA, Ikuo SUMI}

Disaster Prevention System must be reliable and active in confusion brought by hazards inherent in a big earthquake. In this paper, we propose a new approach based on Petri net methodology to deal with this problem. Fist, we classify hazards into two types, i.e., restrictive ones to anti-disaster activities and cutting-off to activities and present their fundamental models by Petri net. Second, we develop a micro system net model in which emergency cars run through the traffic congestion and demonstrate the effect of civic cars as their hazard. Third, we construct a macro net for review of fire protection activities in confusion at quake, using connectivity of Petri nets models developed above, and show its potential as a new methodology for disaster prevention planning. 